\title{
ISLAMIC EDUCATIONAL ADMINISTRATION AND MANAGEMENT PROGRAM, PRINCE OF SONGKLA UNIVERSITY (PSU): CONTRIBUTIONS AND CHALLENGES FOR MALAY MUSLIM COMMUNITY IN THAILAND
}

\author{
Niloh Wae-u-seng \\ Faculty of Islamic Sciences, Prince of Songkla University \\ 15 Karnjanavanich Rd., Hat Yai, Songkhla, Thailand, 90110 \\ Email: niloh.w@psu.ac.th
}

\author{
Abdulhakam Henpiya \\ Faculty of Islamic Sciences, Prince of Songkla University \\ 15 Karnjanavanich Rd., Hat Yai, Songkhla, Thailand, 90110 \\ Email: lugman98@gmail.com

\section{Samsoo Sa-U} \\ Faculty of Islamic Sciences, Prince of Songkla University \\ 15 Karnjanavanich Rd., Hat Yai, Songkhla, Thailand, 90110 \\ Email: samsoo.s@psu.ac.th
}

Received: 05, 2019. Accepted: 07, 2019. Published: 07, 2019.

\begin{abstract}
This study aims at examining the ongoing development of one of the programs offered by FIS i.e., Islamic Educational Administration and Management Program (IEAMP). Documentary analysis is used. The result shows the study program is geared towards making $a^{\prime} b d$ and khalifah concept the mainstream in its course syllabus. The program is the first master program offered in Non-Muslim country, Thailand. Bearing the name of "Islam" is a heavy responsibility. Therefore, it has begun a journey to ensure that a student graduating from this program will be a Muslim graduate equipped with integrated knowledge, skills and abilities; but more, they should be insan, $a^{\prime} b d$ and khalifab; their souls strengthened with Islamic spirituality. IEAMP is just another postgraduate program which is akin to others of its kind under supervision of the Teachers' Council of Thailand and Office of the Higher Commission of Thailand. The program has objective of producing Islamic administrative professional capable of leading and developing Malay Muslim society, in particular, Thai society, in general.
\end{abstract}

Keywords: Islamic Educational Administration and Management, Southern Part of Thailand, Islamic Higher Institution

\begin{abstract}
ABSTRAK
Tujuan penelitian ini adalah untuk. menelaah perkembangan program managemen dan administrasi pendidikan Islam. Analisis dokumen digunakan dalam penelitian ini. Hasil penelitian menunjukan bahwa program studi ini dibuat untuk. menghasilkan 'abd dan khalifah sebagai arus utama nilai dan isi dalam silabus kurikulum. Program studi ini adalah yang pertama untuk strata master di negara non-muslim. Membawa nama "Islam" merupakan tanggung jawab yang berat. Oleh sebab itu prodi ini memulai perjalanan dengan tujuan babwa lulusan akan mengintegrasikan pengetabuan, keterampilan dan kemampuan. Lebih dari itu lulusan harus memiliki karakter insan abd, jiwa mereka barus diperkuat denagn spiritualitas islam. IE AMP adalah program magister yang sesuai dengan dan di bawah pengawasan dewan guru Thailand dan Kantorpendidikan Tinggi Thailand. Program studi ini mempunyai tujuan untuk mnghasilkan profesional di bidang administrasi yang akan mengembangkan pendidikan Islam bangsa Melayu secara kbusus dan masyarakat Thailand umumnya.
\end{abstract}

Kata Kunci: Managemen dan Administrasi Pendidikan Islam, Thailand Bagian Selatan, Pendidikan Tinggi Islam 


\section{INTRODUCTION}

Pattani or Fatoni has been well known as the balcony of Makkah (i.e., a land of Muslim scholars), attributed to the growth of religion knowledge and emergence of Muslim scholars in this area comparable to that of Makkah. A number of Pattani Muslim scholars completed their religious study from Makkah and come back to expand what has been learned there to their homeland (Pattani) and thus religious knowledge which is considered by Muslims as an invaluable heritage has been protected in perpetuity. These scholars have played a remarkable role in the evolution of Islamic education in this area by way of preaching religious teaching and producing Islamic literatures. Moreover, their heritages or legacies are being continuously used in developing Islamic education in this area. It goes without saying that their contribution for Islamic education is great and long lasting for the students learning Islamic education.

Today, southern Thai Muslims receive their religious education from many different sources, both formal and informal. As a result, the 'traditionalist' hegemony over Islamic education in the south is gradually being broken down. Apart from the challenge of 'modernist' modes of education, there are new influences, for example from the increasingly popular Jamaat Tabligh dakwah ('missionary') organization, whose influence stretches from India to Muslim Southeast Asia and beyond, and even the small but significant community of Shi'a Muslims, which has an active program of translating Iranian Islamic scholarship into Thai and a presence in the mass media. Jory (2013) highlights the fact that as Patani's reputation for religious education has declined and the number of foreign Muslims coming to southern Thailand to receive their education has dwindled, Muslim students from the south are increasingly mobile and now travel outside the region to receive their education from a range of places, among them Saudi Arabia, Egypt, Sudan, Jordan, South Asia, Malaysia, Indonesia, as well as Bangkok. While this means that Islamic education in southern Thailand has to a certain extent become decentred, at the same time new 'transnational networks' are being formed among the Muslims of southern Thailand.

The preservation of Islamic studies legacy in Pattani has been primarily undertaken by traditional religious institutions (i.e., Pondok, Tadika, Masjid), however in the latter period till today its preservation and development has been mutually carried out by traditional and modern religious institution (i.e., Islamic Private Schools). Due to the growth of Muslim students studying Islamic studies in overseas and the extension of Islamic studies curriculum being implemented in Islamic private schools as well as public schools, the establishment of higher educational institution in the field of Islamic studies seemed necessary in an effort to provide platform for conducting training, research and producing Islamic studies teachers. Thus, College of Islamic Studies (the name has presently been changed to Faculty of Islamic Sciences) was established in 1989 as the first public higher education in the field of Islamic education offered for Muslims as well as Non-Muslim (who are interested to learn Islam) in Thailand. Under this college, numerous undergraduate programs were offered, namely, Islamic studies, Islamic law, Islamic economic, teaching of Islamic education, and Middle East and Arabic language studies. For postgraduate program, two programs were offered, namely, Islamic Studies Program (offered for both master and Ph. D. level) and Islamic Educational Administration and Management program (IEAMP). Initially, IEAMP was the first Master degree program on Islamic educational management course offered in higher education in Thailand where MalayMuslims are considered as minority group within Buddhist atmosphere.

There are the demands of Muslims on Islamic education development. It was obvious not only in this Malay-speaking Muslim majority provinces namely Pattani, Yala, Narathiwat, Satun and part of Songkla provinces but also in upper south where the Islamic schools have been spread out among Thai speaking Muslims areas (Zehner, 2017). Previous researches have received increasing attention on how to promote the quality of Islamic education towards $21^{\text {st }}$ 
century learning approaches (Al-Ikhlas, Sa-u \& Lateh, 2008; Sa-U, 2013; Sa-U, Ali \& Nordin, 2011) Visalaporn et al. 2011; Hengpiya, 2016). In addition, the studies done by Visaloporn et al. (2011) and Wae-u-seng (2011) delved into the need for embarking on Islamic oriented program in higher educational institutions especially in the south of Thailand. Therefore, this study is different than the previous studies where the previous studies highlighted how the learning approach supports the Islamic education in general, meanwhile, this study is trying to investigate the ongoing development of one of the programs especially for the implemented program, contributions, challenges and prospects of the programs for the Thailand educational development.

\section{METHOD}

This is a qualitative study underpinned the narrative case study research approach. The narrative case study is a research instrument that is used for the in-depth study of various social and clinical problems, to understand stages or phases in processes, and to investigate a phenomenon within its environmental context (Gilgun, 1994). Qualitative case study methodology provides tools for researchers to study complex phenomena within their contexts. When the approach is applied correctly, it becomes a valuable method for scientific research to develop theory, evaluate programs, and develop interventions (Baxter \& Jack, 2008). This study investigated Faculty of Islamic Sciences (FIS), Prince of Songkla University, Pattani Campus, Thailand. The curriculum was analyzed comprehensively to answer the questions related to the implemented program, contributions, challenges and prospects of this program to the Islamic educational system in Thailand. Triangulation was used to collect the data and to analyze the data as well. In data collection, the principal of triangulation aims to find various kinds of sources in order to confirm the relevant information (Rahim, Norhayate, Daud ${ }^{2}$, \& Abdul, 2015). This study used document analysis and interview as the tool to collect the data.

\section{RESULTS AND DISCUSSION \\ Program Implementation}

This section deals with the implementation of Islamic Educational Administration and Management Program (IEAMP) related to educational philosophy, program objective and curriculum. These three aspects will be described in depth to provide bigger picture on the ongoing process of this study program.

\section{Philosophy}

IEAMP is initially introduced based on the educational philosophy that aims to produce graduates who possess various competencies i.e., mastery in theories, researches, and practices; skillful in communication and technology; distinct in administrative profession and integrity; capable of integrating conventional theories with Islamic perspectives within local and regional context (Faculty of Islamic Sciences, 2017). It is clear that the study program has a distinctive in a sense that it tries to integrate Islamic perspective into the study program curriculum.

The development of quality education especially in southern border provinces which differs from other parts of Thailand is directly involved with school administrators as well as educational personnel. Therefore, IEAMP position is paramount to the educational development in Thailand. It is expected to meet with the community's demand and develop the administrators in terms of knowledge and administrative skills. Their good competency and command later on can be used to improve themselves and school organization to their maximum pace according to standard and profession etiquette (Faculty of Islamic Sciences, 2017). 


\section{Objectives}

IEAMP is introduced with the aim to produce graduates possessing competencies based on Thailand Qualification Framework set by Office of the Higher Commission and Teacher Council. The specific objectives of IEAMP are as follows (Faculty of Islamic Sciences, 2017):

1. Serving as a good model in work conduct and personal practice especially in terms of spiritual, ideological, and ethical dimensions.

2. Achieving mastery in their profession i.e., able to plan, to apply theories, and to integrate the conventional perspective with Islamic one for the cause of the betterment of educational administration as well as school administration.

3. Achieving distinction in critical and innovative thinking, communicative skills, technology literacy, data searching and synthesizing, educational leadership, and realization of multicultural education. These competencies and skills become instrumental in managing schools in multicultural society effectively and efficiently.

4. Achieving good command to conduct research as a tool to embark on new body of knowledge and able to apply it to problem solving and education managing effectively.

The above objectives have been designed to meet the demand of producing graduate who are in line with the university' mission in the following areas (Faculty of Islamic Sciences, 2017):

a. Teaching: to produce graduates who are competent in educational, ethical and academic leadership, teaching profession, skills in administration and management, selfdevelopment, active learning, and integration between the conventional and Islamic perspectives for the cause of the nation development.

b. Research: to produce graduates who are capable of conducting research to develop administrative profession through teaching and learning based on student centered approach as well as getting academic staff involved in developing their profession.

c. Academic service: to produce graduates who are internalized with moral integrity, service minded, and sense of common goal superior than self-interest through teaching approach that links with a community and society at large.

d. Preservation of culture and arts: to produce graduates who are aware of the values of arts and local wisdom.

The above four mission covers four aspect namely: teaching, research, academic service and culture preservation. The objective of this study program should be able to meet the requirement of the university mission.

\section{Curriculum}

IEAMP consists of 36-44 total credits. It has 2 modes of study i.e., by research only, and by research and coursework. Each mode of study has its own requirement. By research only requires students to achieve 2 required courses i.e., seminar in research I and II. The second mode of study, the mixed mode, requires students to take various courses covering prerequisite, compulsory, elective, and thesis. In other words, the amount of subject and time to spend is bigger than research only study mode. The following are lists of courses offered by IEAMP (Faculty of Islamic Sciences, 2017).

1. Prerequisite: 7 credits

762-500 English for Administrator

762-501 Foundation of Education

$2(2-0-4)$

762-502 Readings on Islamic Educational Administration

$2(2-0-4)$

2. Compulsory: 29 credits

762-503 Theories and Principles of Educational

Administration and Management

$3(3-0-6)$

762-504 School Administration and Management

$2(2-0-4)$ 
762-505 Curriculum Management, Learning, and

Measurement and Evaluation

$2(1-2-3)$

762-506 Research in Education

$3(2-2-5)$

762-507 Student Affairs Administration

$2(2-0-4)$

762-508 Educational Quality Assurance

$2(1-2-3)$

762-509 Educational Planning and Policy

$2(1-2-3)$

762-510 Innovation and Information Technology in Education

$2(1-2-3)$

762-511 School Supervision

$2(1-2-3)$

762-512 Educational Administration Leadership

$2(2-0-4)$

762-513 Integrity and Professional Codes of Ethics

$2(2-0-4)$

762-514 Professional Educational Administrators

$2(2-0-4)$

762-515 Practicum in School and Educational Administration

762-516 Seminar in Research for Thesis I

762-517 Seminar in Research for Thesis II

3. Elective: 3-9 credits

762-518 Research Seminar in Educational

Administration and Management

762-519 Qualitative Research in Educational

Administration

762-520 Applied Statistics for Educational Administration Research

762-521 Seminar in Issues and Trends of Educational Administration and Management

762-522 Organizational Behavior

762-523 Comparative Educational Administration and Management

762-524 Higher Education Administration

762-526 Private Education Administration

4. Thesis $12-36$ credits

762-627 Thesis

$36(0-108-0)$

762-628 Thesis

$12(0-36-0)$

5. Minor thesis 6 credits

762-629 Minor Thesis

$6(0-18-0)$

It is crystal clear that the subjects provided are designed to meet the need of students taking by research and coursework. As the name implies, the coursework mode of study means taking more subjects to learn in the class to achieve their educational objectives.

\section{Contributions}

Having discussed philosophy, objectives and curriculum, this study moves forward to elaborate a contribution of this study program. Being hailed as the first program introduced in Thailand, IEAMP study program is in a position to cater educational need for Muslim who are regarded as minority population. The study program has played vital roles in producing qualified graduates in educational administration. In addition, it has provided services to the community who also need to receive the benefit of the existence of this study program for their life. The following are some of the contributions having been made by IEAMP. 
1. Developing body of knowledge in educational administration: Theory testing and development

Since IEAMP is conducted in both modes of study - by research only and research and course work - students were encouraged mainly to do research for testing theories using inferential statistics such t-Test, F-test and regression. Mixed methods is to some extent used but very limited in number due to its complexity and comprehensiveness. However, the newly revised curriculum of IEAMP which is effective in the first academic year of 2017 tends to motivate students to rely on the research and development design (R\&D) in order to initiate the administrative innovation. As for the focus of the thesis, most topics focus on school missions stipulated by the National Act 1999, amended in 2010, i.e., academic affairs administration, personal administration, budgeting, and general administrative affairs. However, few students opt to work on other topics related to organizational behavior. These diverse topics are promising academic outcome for the institution, researchers, practitioners and the society in general.

2. Embarking on the contemporary concept of Islamization and integration

As mentioned in the philosophy, IEAMP applies the teaching approach which enables study program to achieve the implementation of the process of "Islamization" and "Integration". It is done across the curriculum. The concepts in the existing knowledge are Islamized or. Another option is that Islamic perspectives are inserted in parallel to the western ones. Its output is clearly noticeable in the thesis.

3. Legalizing administrators' profession

In fact, there are many schools' administrators who have not yet got the certificate for school administration. They were allowed to run their schools with certain conditions and within time frame. To further their study, IEAMP study program will cater their need and pave way to such a certificate.

4. Providing academic services to the community

There are various forms of academic services provided by academic staff of IEAMP. Providing training and workshop on quality school become one of the most salient contributions of IEAMP. However, being consultants in the professional development of both teaching and academic staff of basic educational institutions scattered in the southern provinces seems to be effective and productive. Apart from these, national conference on Muslim and Islamic Studies and post-graduate colloquium are organized to provide platform for students to present their works and researches, thus extending their horizons of knowledge and practices.

5. Expanding opportunity for educational continuation

As far as the local students who were admitted into the IEAMP is concerned, it is noted that their educational qualifications vary. Some of them obtained their first degree from Middleeast countries, Southeast Asia especially Indonesia, Pakistan or even India. It seems that western universities were not their choice for prior degree. This indicates the program give them chance to continue their study through exceptional case basis. In addition, IEAMP also provided opportunity for foreign learners serving as teacher in Islamic private schools in southern border provinces to further their study.

\section{Challenges}

In this section, some challenges encountered by IEAMP are described in depth to provide bigger picture on the ongoing development of this study program.

1. Implementation

Briefly, implementation can be described as the stage of putting the theory learned into effect. A number of students in the program are fully employed in-service school personnel and they joined this program to achieve their goals of expanding knowledge, skills and abilities in 
the area of Islamic educational administration and management. It is often believed that when they finish their studies, they return to their school to resume their entrusted work.

There are several question for each level. At individual level, a basic question is that to what extent these graduate students can bring about change and improve their works by translating the contents learned or knowledge obtained into action. At collective level, a basic question is one of what can be done to raise organizational capabilities to implement theory of educational administration, which require an effective administrative management. To make a practical strategy for handling and responding these questions in their work is a real challenge. A successful handing of this challenge would mean that they can bridge the gap between theory and practice and also able to transform the model extracted from the course syllabus into module, supplemented with action plans that could lead to an organizational goal.

2. Islamic Research Development

Islamic educational administration and management can be considered as a new field in Thailand context. There is still limit of understanding and achievement in the area as compared to conventional theories in educational administration. Therefore, it would be a challenge to the program in its effort to make it generally known to the people in the field. Correspondingly, the task of making publication of written works related to the field of study is necessary. In an effort to achieve this publication mission, the program has made a project proposal to the university for setting up Islamic Educational Administration Research Unit. The primary role of this unit is to assume responsibility of conducting researches in area of Islamic educational administration bound by the university research funding system and also external funding. In addition, it assumed the role of producing scholarly articles in Islamic educational administration for peer-reviewed journals.

The turbulence originating from the Western civilization especially through its secular and Eurocentric education has led to a dualism of education. Education in Islam is seen, therefore, as a restoration of spiritual dimension in curriculum. Thus, our program takes the post of being a spearhead of educational integration movement in the field of Islamic educational administration. The program in educational administration in Thailand is predominantly tainted with scientific worldviews and secularism, thus our program takes it upon itself to uphold and provide real Islamic educational administration towards the building of knowledge foundation in the field of Islamic educational administration. Therefore, the role of translation and textbook writing project in the field become a necessary and urgent agenda which would be carried out by the Islamic Educational Administration Research Unit. This unit focuses on providing reference resources which are based on value-based knowledge and religion. Insha Allah, research, translation and textbook writing project which will be embarked upon will benefit Muslim mind.

3. Innovation Development

The first phase of program implementation (around 2008-2017) predominantly focused on theoretical understanding, theory testing study and survey descriptive research. Specifically, the program emphasized on the identification of problems of the schools in the south of Thailand, narrative description of school administration and management, survey the states of schools using SWOT analysis, and the test of administration management theory in the school context. After getting information regarding the state of schools in relation to their strength, weakness, opportunity and threat, the second phase of program implementation (from 2017 onward) pays much more attention to the development of educational administrative innovation and focuses on research activities that contribute a higher impact and development. Thus, experimental research and developmental research are highly encouraged. As an effort to develop quality educational management that lead to quality education of Muslim community in the southern part of Thailand, the IEAMP has proposed innovation development program 
to be initiated in the near future and some of them are presently carried out. A brief information of these program as presented in Table 1 below;

Table 1: IEAMP's Innovation Development Program to Promote the Quality of Islamic Education (2017)

\begin{tabular}{|c|c|c|c|}
\hline $\begin{array}{c}\text { Program } \\
\text { Development }\end{array}$ & Focused issues & Learning process management & Expected results \\
\hline HIKMAH & $\begin{array}{l}\text { Administrator } \\
\text { Leadership }\end{array}$ & $\begin{array}{l}\mathrm{H}=\text { Hisbah } \\
\mathrm{I}=\text { Inprirtion } \\
\mathrm{K}=\text { Khidmat' } \\
\mathrm{M}=\text { Muamalat/Masyarekat } \\
\mathrm{A}=\text { Amanah } \\
\mathrm{H}=\text { Hikmah }\end{array}$ & $\begin{array}{l}\text { To promote the } \\
\text { strategic planning for } \\
\text { school administrator }\end{array}$ \\
\hline $\begin{array}{l}\text { ISLAMIC } \\
\text { citizenship } \\
\text { education (ICE } \\
\text { project) } \\
\end{array}$ & $\begin{array}{l}\text { Good Muslim } \\
\text { citizenship }\end{array}$ & the participatory leaning activities & $\begin{array}{l}\text { To infuse the Islamic } \\
\text { manners and } \\
\text { citizenship among } \\
\text { student. }\end{array}$ \\
\hline $\begin{array}{l}\text { FADEL } \\
\text { Tecnique }\end{array}$ & $\begin{array}{l}\text { Innovative Arabic } \\
\text { Teacher }\end{array}$ & $\begin{array}{l}\mathrm{F}=\text { Field trip } \\
\mathrm{A}=\text { Analyze } \\
\mathrm{D}=\text { Design \& Develop } \\
\mathrm{L}=\text { Lesson Learnt }\end{array}$ & $\begin{array}{l}\text { To encourage Arabic } \\
\text { teachers to invent } \\
\text { their teaching aids. }\end{array}$ \\
\hline FALAH Model & $\begin{array}{l}\text { Transformative } \\
\text { management } \\
\text { (integration } \\
\text { between } \\
\text { conventional and } \\
\text { traditional } \\
\text { approaches) }\end{array}$ & $\begin{array}{l}\text { Special collaborative project } \\
\text { between the program and } \\
\text { Southern Border Provinces } \\
\text { Administration Centre (SBPAC) } \\
\text { to be set up. The project is aimed } \\
\text { to recruit Baba (master/owner) of } \\
\text { Pondok for the program under the } \\
\text { scholarship sponsored by SBPAC. }\end{array}$ & $\begin{array}{l}\text { To reform education } \\
\text { of Pondok in order } \\
\text { to keep it abreast } \\
\text { with current } \\
\text { development of } \\
\text { education in } \\
\text { Thailand. }\end{array}$ \\
\hline
\end{tabular}

4. Internationalization

The master program's curriculum presently comes in the second phase of its implementation. In this phase, the program doesn't only focus on developing innovation and conducting developmental research, but also focuses on expanding its scope to achieve the goal of internationalization or global expansion. Plans for action has to be developed and numerous programs should be carried out if the program are aimed to achieve the mission of internationalization. The internationalization mission includes plan for recruitment of foreign students with the scholarship supported by the university. The program shall enter into a memorandum of understanding with other universities in Asian countries as to establish academic exchange between universities in form of joint program, visiting lecturer, collaborative research, students' exchange, staff exchange, etc.

\section{Prospect}

In the competitive environment of today world, work in partnership seemed to be getting competitive advantage. Working collaboration between organizations will actually engender a more all-encompassing perspective of organizational development, affected by the exchange of the cultures, values, knowledge, experiences and skills. Each organization has its own strengths and weaknesses, and challenges and opportunities. Islamic models of educational administration from the Malay words that are seemed to be relevant to our program, for example, Indonesia has been known for its best practice on the management of modern Persantren; Brunei Darussalam made an outstanding achievement in quality teaching and learning of religion studies in schools owing to the country's strong stand for Islam in carrying the value of Malay 
Islamic Monarchy (MIB) and Malaysia has successfully implemented an integrated Islamic curriculum at higher educational level. This can be seen in a case of International Islamic University Malaysia (IIUM). It is often believed that by learning Islamic model of administration of others in comparison of own self would help create an ideal model of administration. Therefore, persons in charge of the program have a very strong desire to work in partnership based on mutual benefit cooperation with all countries in the Malay world. This cooperation can help improve our practices in an effort to realize the organization's mission.

\section{CONCLUSION}

This study was aimed at examining the ongoing development of one of the programs offered by FIS i.e., Islamic Educational Administration and Management Program. The focus was given to its contribution and proposal for the development that would result in strengthening the program to achieve the desired goal. Taking into account the importance of educational administration in Islam and the imbalance that exist, Islamic Educational Administration and Management program, Prince of Songkla University (PSU) is assuming a huge responsibility to alter the landscape of postgraduate learning program. Its aim is geared towards making $a^{\prime} b d$ and khalifah concept the mainstream in its course syllabus. The program is the first master program offered in Non-Muslim country, Thailand. Bearing the name of "Islam" is a heavy responsibility. If it is left as a symbol or a simple embellishment, then the program has not accomplished its duty of actualizing the above fundamental concept of Islam. Therefore, we have begun a journey to ensure that a student graduating from this program will be a Muslim graduate equipped with integrated knowledge, skills and abilities; but more, they should be insan of a'bd and khalifab; their souls strengthened with Islamic spirituality.

IEAMP is just another postgraduate program which is akin to others of its kind under supervision of the Teachers' Council of Thailand and Office of the Higher Commission of Thailand. The program has objective of producing Islamic administrative professional capable of leading and developing Malay Muslim society, in particular, Thai society, in general. The graduates of this program would obtain academic transcript and administrative professional license recognized by the Teachers' Council of Thailand. With their professional license, they can make a greater contribution towards transforming Islamic integrated knowledge into practice and applied the Islamic approach to their schools so that curriculum management becomes holistic and gives due regard not only to spiritual matters but also temporal ones. It is strongly believed that the hardship endured by the program to achieve holistic and spiritual approach in educational administration that are, somehow, being permeated to the Islamic traditional institutions would make the institution survived and well-prepared to take on the greater responsibilities and better cope with the present competitive environment and challenges of globalization. As a consequence, Islam and Malay education identity which have been a long-established emphasis in Muslim society would be persistently preserved without neglecting the significant contributions of modern approach of education.

\section{BIBLIOGRAPHY}

Baxter, P., \& Jack, S. (2008). Qualitative Case Study Methodology: Study Design and Implementation for Novice Researchers. The Qualitative Report, 13(4), 544-559. Retrieved https://www.researchgate.net/publication/228621600_Qualitative_Case_Study_Method ology_Study_Design_and_Implementation_for_Novice_Researchers

Faculty of Islamic Sciences. (2017). Syllabus of Master of Education Program in Islamic Educational Administration and Management. Pattani: Faculty of Islamic Sciences, Prince of Songkla University. (in Thai)

Gilgun, J. F. (1994). A Case for Case Studies in Social Work Research. Social Work, 39(4), 371380. https://doi.org/10.1093/sw/39.4.371 
Hengpiya, A. (2016). A Classroom Management Model for Preventing Students' Learning Misbehavior. Al-Hikmah Journal. 6(12), 2-16. Retrieved from https://www.tcithaijo.org/index.php/HIKMAH/article/view/116331

Jory, P. (2013). Islam, Education and Reform in Southern Thailand: Tradition and Transformation. The Asia Pacific Journal of Anthropology, 14(3), 284-286. https://doi.org/10.1080/14442213.2013.787908

Niloh Wae-u-seng. (2011). Research Report on Islamic Educational Provision in Three Southern Border Provinces. Pattani: College of Islamic Studies, Prince of Songkla University. (in Thai).

Moohammadhassan Aslam Al-Ikhlas, Samsoo Sa-u \& Afifi Lateh. (2008). Factor influencing Muslim teachers' perceptions on ethic behaviors of elementary school principals in Thailand". Paper presented at The International Conference on Social Sciences and Humanities, Organized by Universiti Sains Malaysia (USM), Pulau Penang, $18^{\text {th }}-20^{\text {th }}$

Rahim, M., Norhayate, W., Daud, W., \& Abdul, M. (2015). The Case Study Method in Business. Scholars Journal of Arts, Humanities and Social Sciences, 3(1), 105-109.

Sa-U, S. Ali, H. M., \& Nordin, M. S. (2011) ."Chapter 2: Islamic Behavior among Muslim teachers in the Public Primary Schools in the Southern Thailand", In Ali, Othman \& Salleh (Editors). Education Leadership and Management. Kuala Lumpur

Visalaporn, S. et al. (2011). Educational Management Model in Southern Border Provinces, Thailand. Bangkok: Office of the Education Council. (In Thai).

Zehner, E. R. (2017). Muslims, Education, and Mobility in Thailand's Upper South: why they. Journal of Education and Social Sciences. 7(1), 9. Retrieved https://www.jesoc.com/wpcontent/uploads/2017/08/JESOC7_26.pdf 